A member of both the ACRL Publications in Librarianship Editorial Board and the LAMA $L A \& M$ Editorial Board, St. Clair's professional activities include committee service in ALA's LITA and ALCTS divisions and the Library Research Round Table. Her major editorial responsibilities have included the Texas Library Journal, the Georgia-South Carolina College English Association Newsletter, and the Working Papers of the College of Business Administration at the University of Texas at San Antonio. A prolific writer, her work has appeared in College \& Research Libraries, Technicalities, Wilson Library Bulletin, and Journal of Library Administration. She has recently completed, along with Rose Mary Magrill, a study of undergraduate use of library collections funded by a grant from the Council on Library Resources (see pp. 25-28, this issue).

\title{
Bibliographic instruction and
}

\section{accreditation in higher education}

\author{
By Marilyn Lutzker \\ Deputy Chief Librarian \\ John Jay College of Criminal Justice
}

\section{A new combination-accrediting libraries on the basis of how well people are taught to use them.}

ignificant changes are being made in the manner in which libraries are viewed during the all-important higher education accreditation process. The Middle States Commission on Higher Education now expects that each accredited institution have a bibliographic instruction program, and that a library's effectiveness within the teaching/learning environment of the institution be clearly demonstrated.

Characteristics of Excellence in Higher Education: Standards for Accreditation states:

"The centrality of a library/learning resources center in the educational mission of an institution deserves more than rhetoric and must be supported by more than lip service. An active and continuous program of bibliographic instruction is essential to realize this goal" (p. 35).
Howard Simmons, executive director of the Middle States Commission on Higher Education, could not be more forthright in his support of bibliographic instruction. He has written, "As part of the accreditation process it is essential that all...institutions develop a strong program of bibliographic instruction as one means of improving academic quality" [emphasis added] (Bibliographic Instruction, p.11).

In support of this new emphasis, in September 1989, the Middle States Commission on Higher Education held a workshop to discuss methods of evaluating BI programs within the accreditation process. This article is based on the presentation made by the author at that workshop and on the discussions of the workshop participants.

I have three objectives for sharing these ideas 


\section{Fast, effective relief for your reference headaches.}

"I'd like a book by an author I saw on TV last night whose last name begins with 'Sij' and I think the title is Vietnam." "I'm looking for a book with a forward by Coretta Scott King about a slave revolt." "I love old samplers. Are there any books about British samplers that are illustrated?" How many times have you had to help a patron with only snippets of information like the above? Now it's easier than ever to do so - and reduce the time and effort it takes - with Books in Print Plus ${ }^{\text {TM }}$.

Unlike some CD-ROM products, which are nothing more than electronic vendors' catalogs, Books in Print Plus is an important reference tool specifically designed to help you and your patrons find exactly what you're looking for.

\section{Unique, work-saving software makes it simple.}

On-screen prompts, instant help screens, even a special patron mode all insure that you won't waste any time getting up and running with Books in Print Plus. Custom search through the database by combining any or all of up to 18 search criteria. For example, search for all titles dealing with wine, published after 1987, and a list is displayed in seconds. If it is then decided that French wines should be excluded from the search, a simple change will immediately display all titles dealing with wine (with the exception of French wines) published after 1987. The results are so incredible that once you try Books in Print Plus, it will change the way you do reference work forever.

\section{Take two minutes and call us in the morning.}

To order Books in Print Plus for the IBM PC or Apple ${ }^{\circledR}$ Macintosh ${ }^{\circledR}$, or for more information about how you can streamline reference procedures, call Bowker Electronic Publishing toll-free at 1-800-323-3288. In New York, Alaska, and Hawaii, please call us collect at 212-337-7190. You'll be feeling better in no time.

For extra relief, try Books in Print with Book Reviews Plus ${ }^{\text {TMI }}$ with fulltext reviews from Library Journal, Publishers Weekly, School Library Journal, Booklist, Choice, Reference and Research Book News, SciTech Book News, and University Press Book News.

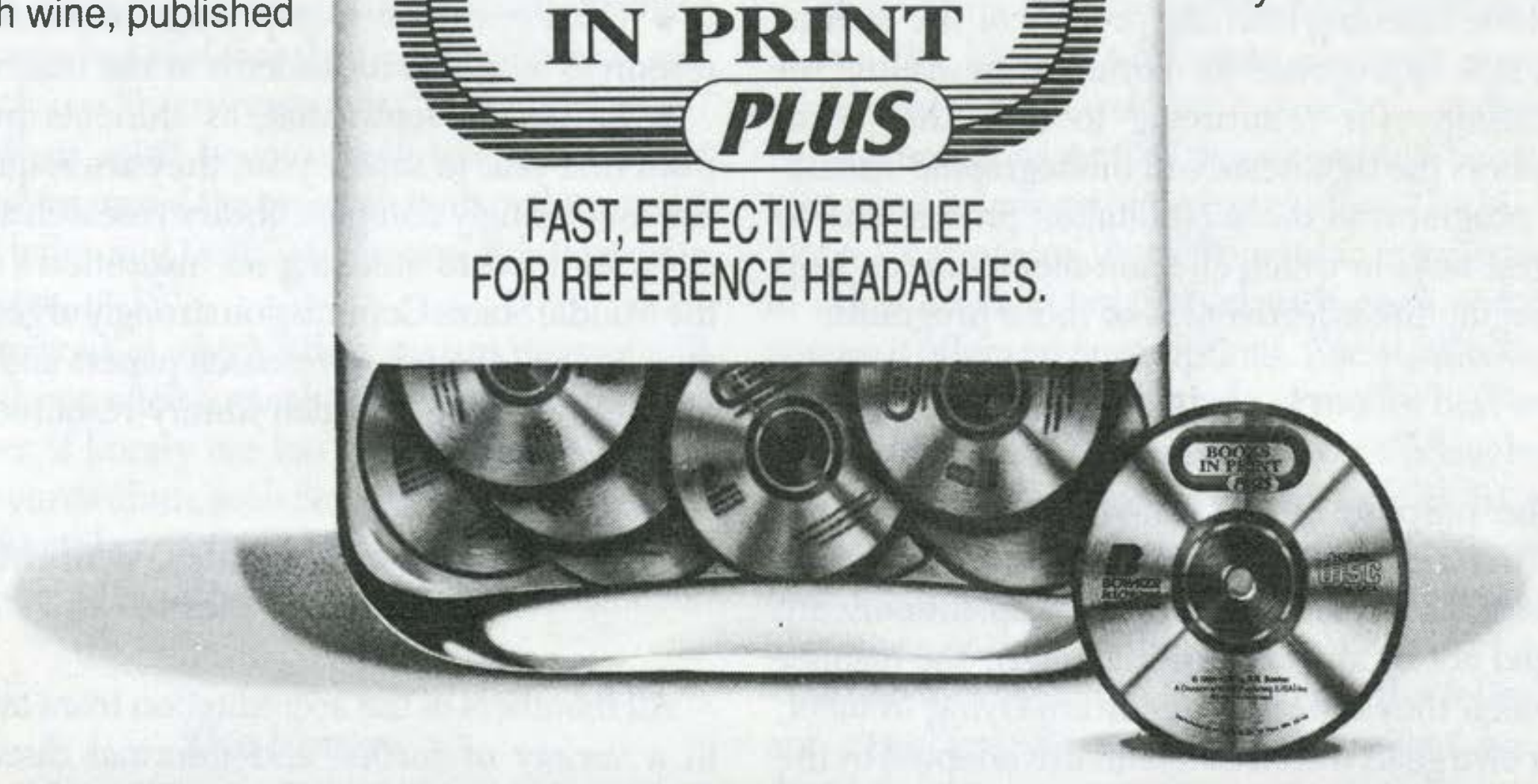


with the broader academic library community: to alert all librarians to the changing emphasis so that they can help their own institutions prepare for accreditation; to provide a tool for those who will be serving on accreditation teams; and not incidentally, to possibly provide some leverage for those who are still trying to convince their library or school administration of the importance of bibliographic instruction programs.

Librarians in academic institutions are generally familiar with the accreditation process. An extended process. It starts with an institutional selfstudy and culminates about 18 months later when a team of experienced educators visits the institution for an on-site evaluation.

Accreditation teams, as the link between the institution and the accrediting body, have a weighty responsibility. In composing these teams, the Middle States Commission tries for a mix of representative administrators and faculty; most teams include a librarian.

\section{Librarians as members of accreditation teams}

Librarians who are selected to serve as members of an accreditation team are, first of all, full members of the team with the same overall charges as all other team members. In addition to these general responsibilities, they are expected-like business managers and systems experts-to serve as special resources in helping the team assess their specialized areas. There have, in the past, been complaints that some librarians tended to take a narrow view of their responsibilities and to limit their participation to matters concerning the library.

With the new criteria, librarians on evaluation teams have an added obligation. Since the library is now to be judged in terms of its effectiveness within the total teaching/learning process of the institution, it is appropriate for librarians to assume responsibility for reinforcing to the other team members the significance of bibliographic instruction programs in the accreditation process and to suggest ways in which all team members can help in judging the effectiveness of those programs.

\section{The self-study}

The purpose of the self-study is to help the institution clarify its own goals and objectives and assess its success in attaining them. Institutions are judged not by abstract criteria, but by the manner in which they are meeting, or are trying to meet, their own goals within the standards adopted by the accrediting association.

The self-study is the major source of information about the institution; all parts of it must be studied with care by all members of the accreditation team.
Evaluators looking for evidence that library instruction and educationally effective library use are integrated into the curriculum should find it in the sections that deal with academic programs as well as in the section on the library. We are looking for clear recognition on the part of all segments of the institution that the bibliographic instruction program is indeed viewed, in Simmons's words, "as one means of improving academic quality."

\section{Syllabi}

It is individual course syllabi that, in a sense, keep the institutional self-study honest. As the teaching faculty's working documents, they reflect the actual instructional modes and practices of the faculty.

The value of looking at course assignments to help assess the educational role of the library is reflected in Simmons's statement that "institutions which seem to have been most effective in getting students to take full advantage of the collections and in promoting the use of resources as a means of improving learning outcomes, have been those in which faculty have strong requirements for library research built into their instructional programs" (Simmons, An Accreditor's Perspective, p. 9).

In assessing course syllabi the following questions might be addressed:

- How many include library-based assignments?

- What is the nature of those assignments?

- Are they appropriate for the school and its students?

- Do they show evidence of thought and creativity?

- Do they promote active learning?

- Do they take advantage of primary sources when appropriate?

- Do they display a knowledge of the range of resources available to students at the institution?

- Is there a sense that, as students progress from first year to senior year, they are required to use increasingly complex library research skills?

In addition to studying an institution's syllabi, the Middle States Commission strongly urges evaluators to look at student research papers and theses to see the extent to which library resources have actually been used.

\section{Discussions with faculty, students, administrators}

All members of the accreditation team take part in a variety of formal and informal discussions during the site visit. The object of these discussions is to find out how well the institution's goals and objectives are realized in practice. In attempting to assess the efficacy of the bibliographic instruction 
program, a combination of unobtrusive and direct approaches are recommended.

In an institution where library use instruction has been integrated into the curriculum, one can reasonably expect that general discussions of the curriculum and of specific programs and courses will include reference to library use. The evaluators should listen carefully to these discussions and note what is-and what is not-said about student use of the library.

As a result of both direct questions and indirect discussions, evaluators should be able to discover whether there is a general awareness of the existence of the bibliographic instruction program and whether there is an understanding of the relationship between library use instruction and the wider educational process of the institution.

Discussions with teaching faculty should help to discern the extent to which they are committed to library research for undergraduates, whether they are aware of the range of materials available in the library for student research projects, as well as the extent to which they view librarians as resource people who can not only offer students instruction in library use, but also help faculty in designing research projects.

In discussions with administrators, we are looking for a clear and committed recognition of the importance of a library instruction program to the overall educational goals of the institution and an acknowledgement of the institution's responsibility to provide adequate funding to support it.

Evaluators are urged to talk to as many students as possible. Such conversations should reveal the role which the use of the library plays in the educational process of the institution. Efforts should be made to determine not only how often students use the library, but in what ways they use it; whether they have been effectively taught how to do independent research; and, most important, whether they themselves feel that they can comfortably and efficiently use library resources. "In the final analysis, students must become self-directed learners who have mastered the research tools in the pursuit of knowledge and truth" (Simmons, Bibliographic Instruction, p. 12).

Discussions at which librarians are present will almost always elicit some description of library use. However, if library use has really been integrated into the curriculum, such descriptions should come forth when librarians are not present. It is important to remind the other team members to listen for them.

\section{The library}

Evaluators might want to look for evidence that the library is being proactive as well as reactive in making itself a vital part of the institution's teach- ing/learning process. The Middle States Commission's standards for accreditation state that "excellence in the professional staff for the library is measurable in part by the extent to which they are active participants in the academic enterprise, not merely custodians" (Characteristics of Excellence, p. 36). Evaluators will assess whether librarians are moving in that direction.

When talking to librarians and library administration, the following are among the specific issues that might be addressed:

- What is the level of administrative commitment to the BI program? When funds or personnel are scarce, what gets cut first? Is there administrative support for experimentation with new approaches and new formats? Does the administration actively promote the instruction program?

- Are the librarians who are doing the instruction enthusiastic and well prepared? Are they knowledgeable about learning theory and pedagogical methods as well as about the resources of the library? Are they sufficiently familiar with the curriculum, students, and faculty to be able to work with teaching faculty in designing research projects?

- Is the entire library staff supportive of the BI program? If there are departmental liaisons, do these people represent the instruction program as well as the collection development program? Are the librarians who participate in the instruction program treated as equals by their peers? Are they resented by their peers as having special privileges? Are they given adequate preparation time?

- Is the literature of the library instruction movement adequately represented in the library's own collection?

\section{The bibliographic instruction program}

There are many ways of teaching students how to use the library. Adherents of credit courses, workbooks, course-related instruction, audio-visual presentations, or CAI can sometimes be rather vehement in support of their own ideas. The Middle States Commission, in bibliographic instruction as in other areas, is concerned with goals and outcomes; it offers no prescriptions. Each institution is left to determine which mode or modes best serve its objectives and the needs of its own student body. Evaluators are cautioned not to look at BI programs with preconceived notions of which mode is best, but to judge the program within the goals and objectives of the institution.

When looking at the BI program, the following are some specific questions that might be addressed:

- Is there a formal statement of objectives for the program? To what extent are those objectives being met? 
- How does the program fit with the teaching/ learning environment of the institution? Is the program teaching what students need to know?

- Is the program a coherent, incremental one with instruction available for all levels of students, freshman through graduate?

- Is there internal evidence of quality and caring? Are instructional materials appropriate and produced attractively?

- Is there recognition of different learning styles?

- Are students taught the type of research strategies necessary for them to become independent learners?

\section{Conclusion}

This brief paper, summarizing the presentation and discussion at the Middle States Commission's workshop, was written to alert those who will be evaluated as well as those doing the evaluations to a changed perspective in the viewpoint of at least one of the major organizations charged with regional accreditation.

The Commission on Higher Education is now alerting institutions to the increased emphasis on educational effectiveness in the accreditation process. Administration, organization, facilities - too often the major focus of attention in the past-will now be examined in terms of their effect on teaching and learning.

We are being told that wonderful library collections are no longer sufficient: students must learn how to use them. We are being told that bibliographic instruction programs are an essential ingredient in the educational process.

Some of us have waited a long time to hear this!

\section{Bibliographic note}

The Commission on Higher Education is one of three divisions of the Middle States Association of Colleges and Schools. The Commission on Higher Education frequently refers to itself as the Middle States Commission on Higher Education, the Middle States Association, or CHE/MSA. It is the official accrediting organization for the states of Delaware, Maryland, New Jersey, New York, Pennsylvania, and for the District of Columbia, Puerto Rico, the Republic of Panama, and the Virgin Islands. Address: 3624 Market Street, Philadelphia, PA 19104.

Commission on Higher Education. Middle States Association of Colleges and Schools. Characteristics of Excellence in Education: Standards for Accreditation. Rev. ed. Philadelphia, 1989. (This is the Commission's primary statement of standards.)

Commission on Higher Education. Middle States Association of Colleges and Schools. Handbook for Evaluation Team Members. Philadelphia, 1989 .

Simmons, Howard L., “An Accreditor's Perspective: Bibliographic Instruction as a Tool for Learning." Speech presented to the Library Association of the City of New York (LACUNY) at Borough of Manhattan Community College. New York City, May 19, 1989.

Simmons, Howard L., "Bibliographic Instruction as a Tool for Learning: An Accrediting Perspective." CHE Letter, Summer 1989, pp. 11-12.

Simmons, Howard L., "Transitions: Retrospect and Prospect; Annual Report of the Executive Director, 1988-89," CHE Letter, Summer 1989.

\title{
Bibliographic instruction or information literacy
}

\author{
By Hannelore Rader \\ Director, University Library \\ Cleveland State University
}

Since the ALA Presidential Committee on Information Literacy issued its final report in January 1989, many librarians, including members of the ACRL Bibliographic Instruction Section (BIS), have been discussing, sometimes heatedly, how information literacy relates to bibliographic instruction. Before the 1989 ALA Annual Confer- ence in Dallas, BIS sponsored a second Bibliographic Instruction Think Tank (the first BI Think Tank was held before the 1981 ALA Annual Conference in San Francisco), to explore the future direction of bibliographic instruction. Details of the second BI Think Tank are provided in "Educational Roles for Academic Libraries," C $\mho R L N e w s$, 